\title{
Književni dani u Raurisu - Rauriser Literaturtage
}

Rauris, Austrija, 4. - 8. travnja 2018.

DOI: 10.21066/carcl.libri.2018-07(01).0013

Od 4. do 8. travnja 2018. književnost za djecu i mlade uzdigla se visoko iznad svih ostalih književnih žanrova. U bajkovitom planinskom mjestašcu Raurisu, u pokrajini Salzburg, dospjela je gotovo do 1000 pa i 1500 metara nadmorske visine. Prvi put u 48 godina otkako književnost zalazi u to selo, taj se znameniti književni festival posvetio, između ostaloga, i književnosti za djecu i mlade. Taj je književni događaj u Austriji drugi po važnosti, odmah iza godišnje prestižne nagrade nazvane po književnici Ingeborg Bachmann (Bachmann Preis), koja se dodjeljuje u Klagenfurtu.

Od 2013. književni se dani u Raurisu odvijaju pod intendantskom palicom Manfreda Mittermayera, germanista na Sveučilištu u Salzburgu i gimnazijske profesorice Ines Schütz. S obzirom na to da je moto ovogodišnjega izdanja bio Frühe Jahre, odnosno rane godine, književnost za najmlađe pokazala se nezaobilaznim oblikom književnoga stvaralaštva, ali i tržišta.

Književni festival Rauriser Literaturtage, na kojem su od njegovih početaka ranih sedamdesetih godina nastupili brojni velikani književnosti njemačkoga govornoga područja, poput H. C. Artmanna, Petera Handkea, Petera Turrinija, Hansa Magnusa Enzensbergera, Friederike Mayröcker, Thomasa Bernharda, Herte Müller i drugih, odvija se u doticaju s prirodom i lokalnim stanovništvom idiličnoga ruralnoga, ali turistički razvijenoga mjesta koje zajedno s obližnjim selima broji oko 3000 stanovnika. U pet dana posjetitelji imaju mogućnost vidjeti, poslušati pa i osobno razgovarati s petnaestak autora iz Austrije, Njemačke i Švicarske. Neka od imena ovogodišnjega izdanja, koja vrijedi spomenuti, svakako su Benjamin Lebert, Paulus Hochgatterer, Peter Henisch i Felix Mitterer, ili pak pjesnikinja Margret Kreidl. Dobitnici su prestižnih nagrada, svojevrsne nove književne nade, Bečanka Raphaela Edelbauer (1990.) za eksperimentalni prvijenac Entdecker. Eine Poetik (Otkrivači. Poetika), u kojem se jezik i prirodne znanosti upotpunjuju i zajedno otkrivaju nove svjetove, te Salzburžanin Florian Gantner (1980.) za pripovijetku Dakizo, u kojoj promišlja o protestnim ritualima suvremene djece i mladeži te pokušava otkriti postoji li granica između igre i otpora. Ustroj je festivala takav da se čitanja i susreti s autorima odvijaju u intimnom, neformalnom i neakademskom okruženju i to gotovo uvijek za stolom, jer se autori s publikom susreću u lokalnim gostionicama, pa i u planinarskom domu na 1500 metara nadmorske visine.

Ovogodišnje izdanje nije bilo posvećeno isključivo dječjoj književnosti, nego djetinjstvu općenito: o svojem ili tuđem, u svakome slučaju fiktivnom djetinjstvu, autori književnosti za odrasle u svojim djelima pripovijedaju s manje ili više intenziteta $\mathrm{i}$ učestalosti. S druge strane, u autora je dječje književnosti djetinjstvo motiv sine qua non, neka vrsta očaranoga doba i prostora iz kojega pisci crpe energiju i inspiraciju te koji, istovremeno obogaćuju novim tekstovima i tako potiču dječju maštu. Maštanje i sanjarenje nisu oblici mentalnih radnja koji su prisutni isključivo u djetinjstvu; naprotiv, i odrasli se često i rado služe njima kako bi se odvratili od stvarnosti pa se u tom smislu spontano nameće promišljanje o važnosti i aktualnosti dječje književnosti za svaku životnu dob. Mašta može svašta. Tomu svjedoči i trenutačna popularnost takozvane all-age ili crossover 
književnosti, odnosno književnosti koja se ne obraća eksplicitno djeci ili odraslima, nego u kojoj mogu uživati svi - svatko na svoj način.

Na ovogodišnjim je književnim danima u Raurisu dječju književnost predstavljao višestruko nagrađivani gradišćanski autor Heinz Janisch, koji je u svojem razgovoru sa studentima germanistike Sveučilišta u Klagenfurtu istaknuo potrebu da se dječja književnost demistificira i oslobodi okova koji su joj nametnuti odozgor, smatrajući ju sadržajno i estetski ravnopravnom pretencioznoj „ozbiljnoj“ književnosti odraslih krugova. Janisch je strastveni pripovjedač: njegove su priče književne minijature o prijateljstvu, a do izražaja najbolje dolaze kada se sljubljuju sa slikovnim elementima slikovnica koje ih upotpunjuju. Književnost za mlade zastupala je darovita Elisabeth Steinkellner, nositeljica Austrijske nagrade u području književnosti za djecu i mlade (Österreichischer Kinder-und Jugendbuchpreis) za 2017. godinu, s kojom su razgovor vodili studenti germanistike iz Graza. Steinkellner je autorica romana o odrastanju i rastajanju Rabensommer, a zanimanje čitatelja i kritike mami posebice svojom lirikom i kraćim pripovijetkama u kojima se također hvata u koštac s izazovima i previranjima mladih u pubertetu. To je dvoje pisaca uspjelo svoja djela dodatno približiti mladim čitateljima i nazočnoj publici, osobito djeci predškolskoga i školskoga uzrasta s kojima su se upustili u ozbiljna, ali zanimljiva književna razmatranja.

Nakon ovogodišnjega prvoga predstavljanja dječje književnosti i književnosti za mlade na književnim danima u Raurisu preostaje nada da će, u idućim izdanjima, ta kategorija književnih djela od slučajnoga prolaznika postati uvaženim i stalnim gostom.

Vito Paoletić

\section{Osma godišnja skupština Hrvatske udruge istraživača dječje književnosti} Zagreb, 12. svibnja 2018.

DOI: 10.21066/carcl.libri.2018-07(01).0014

Osmu godišnju skupštinu Hrvatske udruge istraživača dječje književnosti (HIDK) ugostio je u ugodnu ambijentu Hrvatski školski muzej u Zagrebu, a okupili su se članovi iz različitih dijelova Hrvatske. Na samom početku Skupštine, na prijedlog Predsjednika HIDK-a, jednoglasno je odlučeno da se Ranka Javor imenuje počasnom članicom HIDK-a s doživotnim članstvom, čime joj se odaje posebno priznanje u znak zahvalnosti za njezin velik doprinos razvoju istraživanja dječje književnosti u Hrvatskoj, prikupljanje i čuvanje građe $\mathrm{i}$ izniman angažman u aktivnostima HIDK-a.

Radni je dio Skupštine započeo izvješćima o radu HIDK u protekloj godini, a ipak je u svakom izvješću prevladavao razgovor o planovima za budućnost. Skupštinu su obilježili entuzijazam, brojnost ideja i ugodno druženje. Također su prihvaćeni financijsko izvješće za prethodnu i financijski plan za sljedeću godinu.

Izvješće o radu časopisa Libri \& Liberi: časopisa za istraživanje dječje književnosti $i$ kulture iznijela je glavna urednica Smiljana Narančić Kovač. Prošlo godište časopisa, šesto po redu, objavljeno je prema dosadašnjem konceptu s ukupno devet znanstvenih radova. Posebno zadovoljstvo urednica je izrazila rubrikom Građa objavljenom u drugome broju. Naime, kronologiju hrvatske dječje književnosti od početaka do 1918. godine pripremili su Berislav Majhut i Dubravka Težak. Taj dvojezični i grafički lijepo uređen prikaz pruža do 